\title{
A CRITICAL STUDY OF INDIAN DIASPORA THROUGH THE NAMESAKE BY JHUMPA LAHRI
}

\section{Mr. Jatin Kapadiya}

\section{Introduction of Research Scholar}

Mr. Jatin Kapadiya has been working as an assistant professor in Alpha College of Engineering and Technology, Khatraj - Gandhi Nagar. He is pursuing PhD in English Literature from H N G University. He has 3years of experience in teaching. He has been teaching Communication skills, Soft skills and Personality development to UG and PG students since 4years. He has been presenting papers into various nationals as well as international conferences since his post graduation.

\section{Email: kapadiyajatin@gmail.com}

\section{Abstract:}

In this paper researcher does a critical study of the very famous novel Namesake written by Jhumpa Lahiri. In this novel author has endeavoured to describe the mentality of Indians who are in abroad. How they are confronted with the daily issues related to many things like religion, education, culture, belief system, identity crisis and so on. Researcher here has done a critical study of both the movie and the novel and reach the conclusion with the special reference to Indian Diaspora.

\section{Introduction}

The word "Diaspora" is derived from a Greek word meaning spreading. Jewish people used this word for signifying their world-wide spreading outside their homeland, the Land of Israel. Diaspora was called Golah in, means "Exile". Meanwhile the Jewish people declined to assimilate and were challenged with repression. Jews lived due to immigration, adaptation to the new countries and adhered to their confidence and civilizations. Migration also drawn-out the limits of the Jewish Diaspora. The perfection of Jewish Diaspora was followed by the Armenian, Chinese, African and Indian societies. The alteration with the Jewish Diaspora is that Indian societies have been discrete owed to their selected countries of relocation. Notwithstanding, some limitations of specificity of the idea of Diaspora, it is profitably working in the analysis of emigration and settlement of people outside the limits of their homeland. Retention of the cultural identity in the swarm society is additional significant parameter of the idea Diaspora. There is already substantial literature on numerous Diasporas such as the Chinese, African and Caribbean also the Jewish. Likewise, research on external Indians is also being approved out today under the evidence of Diaspora Studies.

The derivation of the Indian Diaspora has continuously been the provincial social constructions of the emigrants and migrants. On the foundation of provincial cultures and languages in Europe, Indians make 
Towards Excellence: An Indexed, Refereed \& Peer Reviewed Journal of Higher Education/Mr. Jatin Kapadiya/ Page 1-9

their Punjabi, Bengali and Telugu Diasporas. Though, once there is a query of the Indian Diaspora, they continuously touch a portion of it. It is the common cultural inheritance of Indians which lays the basis for the Indian Diaspora. Globalization of the Indian diaspora had previously on-going throughout the migration period to the estate colonies.

Indians have been traveling to various parts of the world from ages ancient. The earliest migration of Indians may be drawn to the trade and spiritual contacts with additional societies similar the Greek and the Mesopotamian. According to Tinker, "The Palas of Bengal remained in interaction with the Sailendra kings of Indonesia. Then in the eleventh century the Cholas pre-arranged voyages which beaten the great Indonesian Empire of Sri Vijaya." Populace movements in the ancient stage never ran to any creation of enduring Indian payments overseas. Indians had trade links with the East Africa, by numerous groups such as the Ranyas, the Ismailis, the Hhoras and the Chettiyars below the exceptional of Nattukottai Chettiyar Association.

Most of the literature on the Indian Diaspora deals with the Indians who migrated during the colonial period, especially from 1830s to 1930s. The British rule and its influence on the Indian peasantry, the famines, and the consequential monetary backwardness have caused in form redundancy. The institution of Slavery was striped by the British in 1830s which shaped a severe labour shortage in sugar plantations of the British and European colonies. This situation gave birth to the indenture form of labour from India and other parts of Asia. Much of the recruitment of this form of labour was done form Western Bihar, Uttar Pradesh, Bengal and Orissa. The system of agreement labour came up originally to overcome the labour lack following the ban on slavery. But the life as plantation labour was rigid that the 'indenture form' of labour, according to Tinker was a "new system of slavery."

The immigration in the post- colonial period was completely dissimilar when associated with the previous forms of migration in the ancient-medieval and the colonial stages. Here the emigrants are from the middle-class, with Instruction in English, and were accomplished. The instructive system in the post Independent India was decorative after the British and American educational organizations. The organization shaped specialists who outstripped the obtainability of jobs that can engross them. In a condition conquered by underemployment and joblessness, the potential immigrants were attracted with the obtainable opportunities abroad. This led to a caring of professional immigration, often termed as 'brain drain', facilitated with the rapid transformations in the transportation and communication. The immigration was mainly to the industrialized nations of the West- the U.S., the U.K., and certain in the Europe and Australia. According to Nayyar (1994: 13), the elementary features of migration from India to the developed world are:

$\checkmark$ Such employment discharges are made up nearly entirely of enduring migration in so far as the quantity of emigrants, who returned to India, after a determinate period, is virtually insignificant.

$\checkmark$ A huge proportion of the immigrants are persons with professional know-how, technical experiences or other skills apparent to be scarce or needed in labour- introducing countries who would be at the upper-end of the range of incomes in India even beforehand migration.

$\checkmark$ For an irresistible proportion of these migrants, the terminuses are the U.S., Canada and the U.K., perhaps because of the shared ties with English language. Apart from the above details, as said before the potential immigrants are educated in a shape that is set up by the British and the American shapes. Moreover they are acquainted with the party-political and economic principles 
Towards Excellence: An Indexed, Refereed \& Peer Reviewed Journal of Higher Education/Mr. Jatin Kapadiya/ $\underline{\text { Page 1- } 9}$

of the West and keep in interaction with those who are previously present in the host or getting countries.

Jhumpa Lahiri's Interpreter of Maladies recognized this young writer as one the greatest brilliant of her age group. Her stories are one of the very few introduction works and only a trickle of collections to have won the Pulitzer Prize for literature. Among the numerous other awards and honours it received were the New Yorker Debut of the Year award, the PEN/Hemingway Award, and the uppermost critical admiration for its elegance, acuity, and sympathy in detailing lives elated from India to America.

In her novel The Namesake, Lahiri improves the themes that completed her collection an international bestseller: the migrant knowledge, the clatter of cultures, the fights of assimilation and most movingly, the tangled ties between peers. Here again Lahiri shows her skilful touch for the perfect detail the brief moment, the turn of phrase that opens entire worlds of feeling.

The Namesake presents the Ganguli family from their tradition certain life in Calcutta finished their fraught alteration into Americans. On the heels of their decided wedding, Ashoke and Ashima Ganguli relax together in Cambridge, Massachusetts. An cause by training, Ashoke familiarizes far less cautiously than his wife, who fights all things American and longs for her family. When their son is instinctive, the task of identification him betrays the annoyed results of bringing old habits to the new world. Named for a Russian author by his Indian parentages in reminiscence of a disaster years beforehand, Gogol Ganguli distinguishes only that he hurts the load of his inheritance as well as his odd, adventure name.

Lahiri transports great understanding to Gogol as he blunders along the first-generation trail, scattered with contradictory loyalties, comic diversions, and spraining love matters. With all-pervading insight, she discloses not only the important power of the names and prospects gave upon us by our parentages, but also the incomes by which we gradually, sometimes excruciatingly, come to describe ourselves.

\section{Diaspora in the Namesake}

The story has so many diasporic involvements such as language as a fence, estrangement, cultural individuality, name and individuality, relationship between parentages and children and homesickness. The novel is a story about the assimilation of an Indian Bengali family after Calcutta, the Ganguli, into America, over thirty years. The cultural battle knowledgeable by them and their American born children in dissimilar ways, the three-dimensional, cultural and expressive displacement agonized by them in their exertion to settle home in the new land. Like many "expert Indians" who in the surfs of the early sixty's, went to the joint states, as share of the brain drain. Ashoke Ganguli too greeneries his homeland and originates to America in chase of higher studies in the field of fibre optics, with a view of location down with safety and admiration.

Afterward two year's stay in the USA he comes back to India, marries a nineteen years old Bengali girl from Calcutta called Ashima, who has no impression or dream of going to a residence called Boston so far off from her parentages, but decides for the marriage. Subsequently the permissible bureaucracies, she hovers unaccompanied to be with her husband, with a weighty emotion and lots of orders from her family associates and families who come to see her off at Dum Airport not to eat complaint of attire kilts or cut 
Towards Excellence: An Indexed, Refereed \& Peer Reviewed Journal of Higher Education/Mr. Jatin Kapadiya/ Page 1-9

off her hair and disremembers the family the moment she property-owning in Boston. Ashima often feels upset and homesick and tempers alone in their three room bed-sitter which is too warm in straw-hat and too cold in the season, for detached from the explanation of house in the English novels she has read. She feels spatially and expressively disrupted from the contented home-based of her father full of so numerous loving ones and yearns to go back. Home is 'a mystical place of desire' in the settler mind.

Greatest of the time she leftovers lost in the reminiscences of her home rational of the actions going there by calculating the Indians time on her hands which is ten and a partial hours gaining in Calcutta. She devotes her time on revisiting Bengali short floors, poems and object from the Bengali fortnightlies, she has transported with her. She saves her ears skilled, amid the hours of twelve and two, for the comprehensive of the postman's paths on the portico, shadowed by the lenient clack of the mail slit in the door, waiting for her parent's letters which she saves gathering in her white basket and revisits them often. But the most frightening knowledge for her is 'Maternity in a foreign land', so far from homebased, unmonitored and unnoticed by those she loved, without a single grand parental or parent or uncle or aunt at her side, and to increase a child in a republic, where she is connected to no one, whose she distinguishes little, where life appears so hesitant and replacement.

She is only charm in the novel that integrates to the American melting-pot familiarizes herself to a transcultural existence at the end. As propose by Alfonso-Forero, "the indeterminate young woman we meeting in the novel's inaugural sheets trying ineffectively to re-form a favourite Indian nosh in her Massachusetts kitchen is distorted through her role as a migrant mother and wife into a international number". The main aim for Ashima's movement in the American society is the difference between two very problematic cultures. America and India culturally, they have vital alterations. Though women and men appear to be similarly independent in America, there are convinced cultural individualities in the Indian viewpoint as to the role of the sexes in civilization. Ashima is the most mystical and Indian number of the family. Where there is an aide-mémoire of India and Indian taxes. Ashima is at the emotion of the material. She founds recurrent parties with the requested Indian families in America the ring of which produce larger each year to uphold the Indian taxes and make replacement India in America.

The difference among the substantial and the mystical in the field of culture is indispensable to how patriotism attempts to resolution the women's question. The division amid ghar - the home, an integrally mystical and female interplanetary and bahir the outdoor world, which is integrally male and conquered by material chases controls not only the separation of labour in rapports of how the Indian home is track, but more prominently it locations women as the guardian and spreaders of Indian culture. In this way Indian patriotism raises the disorder of the middle class woman to a goddess like position.

It is confidential the house that India should be conserved, for the outside is unavoidably America. This is what Ashima is annoying to do all the time to reservation her family's Indian individuality against the application to assimilate. Slowly Ashima absorbs how to be self-governing. Takes pride in education up the child, changes out alone in the marketplace with her baby, interconnects with the passers-by who beam at him and goes to meet her husband on the site, she grows self-assured. The very feeling of movement is touched more by her, after their immigration from the university bed-sitters to a college town outdoor Boston, when Ashoke is borrowed as an Assistant lecturer of electrical Engineering a university. The change to this residential area with no thoroughfare lights, no public conveyance, no 
Towards Excellence: An Indexed, Refereed \& Peer Reviewed Journal of Higher Education/Mr. Jatin Kapadiya/ Page 1-9

supplies for much makes Ashima feel more radical more upsetting than the change from Calcutta to Cambridge had been.

Sensation isolated and expatriate in distant land Ashima instigates to understand that, being a foreign is a sort of enduring gravidity a continuous wait, a continuous load, a continuous sensation out of categories. It is an on-going accountability, a digression in what had when been normal life, only to determine the preceding life has disappeared, substituted by somewhat more complex and difficult. Like gravidity, being a stranger, Ashima trusts, is somewhat that provokes the same inquisitiveness from strangers, the same mixture of pity and respect." By way of times dynamisms by, Ashima spoils this woman more in the American way of life which slowly delivers her through the sort of sureness and individuality that a characteristic American woman is hypothetical to have. She finds a job as a librarian which results in more contact with the outside world and becomes friends with her American colleagues, a kind of relationship that she had never experienced before; she eventually does her husband's duties like paying the bills, buying tickets, driving the car and changing the house which she never did before his death. She later realizes that her life in America exceeds her life in India: she is as much American as Indian.

She gains cultural and geographical variability by the very repetition of her life finished the periods. After her husband dies, she chooses to division her time between India and America: alive between her ancestries in India and her family in America. Thus is Ashima's alteration to a transnational figure, "true to the meaning of her name, she will be deprived of borders, deprived of a home of her own, a resident ubiquitously and nowhere".

Ashoke, is also an significant figure in the story. He is a important character both for the family and for Gogol as the character. His accident in the train in India, his choice and effort in poignant to America and his death in America are three ways in which he is significant to the novel. Ashoke has seen inferior disasters in his life; the train coincidence in which he supposed he was dead in one such event; when his Pullman mate was found dead, he was astonished to be alive. The novelist imprisonments his moment of disaster in the following arguments: "He recalls believing that he was disappearing, that perhaps he was previously dead. He could not touch the lower half of his body, and so was ignorant that the mangled limbs of Ghosh were swathed over his legs. Eventually he saw the cold, unfavourable blue of first morning, the moon and a few stars still lasting in the sky".

His release from the train by land a page of Nikolai Gogol's book and plummeting it to entice the attention of the saviours was a strong and constant reminiscence for him which advanced produced him to name his son after the Russian author. It was an loving relic of his personal life, told to Gogol, the character, by the time that he had previously begun to hate his name and had altered it. His death is also very significant since, it is a rotating point in the lives of the other fonts both physically and expressively. It is through his nonappearance that Ashima and Gogol arrive and gain new and dissimilar insights of life and make vital changes to their lives. Afterward Ashoke dies, Gogol disruptions up with his American girl friend Maxine and is more worried about his family and recalls some of his suppressed Indian lateral of independence, particularly by taking his mother's information to marry Moushumi, a family; not only does she have to living alone but she also has to boundary her habits of life to the American side of the domestic and do the home responsibilities which were beforehand taken by Ashoke. 
Towards Excellence: An Indexed, Refereed \& Peer Reviewed Journal of Higher Education/Mr. Jatin Kapadiya/ Page 1- 9

The unsafe condition in the novel comes when Gogol, the son of the Ganguli's produces up and is unprotected to the dilemmas of the culture which his parentages had been opposite ever meanwhile they set their foot in America. While his parentages had to wrestle with the reminiscences and the coldness of and from the motherland, Gogol has to contend with both the culture and custom which how he is a share of it. The plight of the second cohort has been reduced in the novel in the most beautiful style which at once pushes to classify the fonts. The novel pivots around these two fundamental characters - Ashima and Gogol which sum up the quandaries and difficulties of two dissimilar viewpoints. The first and second cohort migrants have dissimilar woes to relate to and Ashima and Gogol exemplify those torments to excellence. One of the most important characters of the settler being is the arresting of equilibrium between the two worlds - the motherland and the accepted one. The love and admiration for one's culture and origins is never out of mind and the first cohort migrant continuously expects his/her children also to admire the same roots and culture which he/she is an off sprout of. For that reason, the child is made acquainted with the cultural foodstuffs of his republic by the parents the myths, stories, literature, etc. But the position of the cultural sunglasses of the accepted land can't be deserted.

The upcoming of the second cohort lies there and he must be complete to learn the individualities of that culture too. The Ganguli's help many Indian - Americans everywhere them which is done to dismiss their past history and civilizations - to rouse the home country which is far. Robert Cohen commentaries, "A member's devotion to a diasporic community is established by an acceptance of an avoidable link with their past immigration history and a sense of co-civilization with others of a similar contextual". They get together at all spiritual centenary and rites at each other's houses only to obtain a "little India" which they all treasure.

When Gogol is born at a infirmary in America, it is more than a month subsequently Ashima's grandmother, earshot about her pregnancy, has sent a letter which covers two names: a girl's and a boy's. The communication does not reach until Ashoke and Ashima choose to put the pet name "Gogol" in the birth credential to announcement him from the hospital rendering to the American law that the birth certificate should comprise a name. The letter covering Gogol's unique or actual name is lost and the grandmother who has exposed the name to nonentity dies after a coma. Thus the name is inattentive, but it is also current since everyone knows that it happens somewhere but as Heinze says it is "lost in transportation". The similarity of Gogol's life story which his name's fate likewise draws his individuality into consideration: Gogol's uniqueness and the sense of self are in enduring transportation. It is never brought to him until the end of the story.

Rendering to Henize, Gogol's name is singular. This is since it has no senses for Gogol. It is neither a first name nor a last name in America or India, the two seats that Gogol distinguishes and is close with. He cannot imagine his joining with the last name of a Russian writer. This "distinctiveness" of his first name scares and displaces him chiefly after he learns around the absurdity of the Russian author at school as a mentally anxious genius. This is the commencement of his abhorrence of his name. He is scared to present himself as Gogol to the girl whom he kissed for the leading time in his life. So he speaks to her that his name is Nikhil, additional name which was optional by his parents as a good name but had never been rummage-sale: by doing this "not only does he vicissitudes his 'overcoat' and his presentation towards others but he also vicissitudes who he is, if that incomes his past, the multifaceted concoction of his individual and cultural individuality up to this point". 
Towards Excellence: An Indexed, Refereed \& Peer Reviewed Journal of Higher Education/Mr. Jatin Kapadiya/ Page 1-9

Ultimately, his variations his name to Nickhil formally at the court, a alteration which makes him a dissimilar person but also scratches him off from his national past, and his family. Here is no past to be recognized by the new name. Still, he is called Gogol by his individual family and the people who distinguish him from the past. He feels like an actor. "At times he textures as he's cast himself in a play, temporary the part of twins, vague to the bare eye yet basically different". This new excellence of charm which is shaped in him by altering his name while the other is lawful among his family and he connected network of friends from the past is mentioned to as "double" by Heinze. By incoming university in additional city he splits himself from his family physically. After this he can entitlement the new world and personal individuality for himself in a place where everyone would know him as Nikhil. 'Nikhil is his overcoat which brands the ways in which he is dissimilar from other American invisible'. It is in this stage of his life that he instigates his several relations with girls who know only his additional name.

But it is also after altering his name that he is troubled by the knowledge of his namesake bare to him one day by his father in the car. It is hard to propose how this knowledge touches Gogol but positively he is not impermeable to the newscast. He can't hide his being seemingly offended by being told about this after so many years but it is a unforeseen shock for his to anticipate more around his name and his liking for his family and particularly for his father. This is what demonstrations itself more clearly towards the end of the novel is when Gogol is sedentary at his parent's home reading, "the overcoat" for the first time since he was given the book when he was fourteen. It was a gift from his father with his script on the front endpaper "For Gogol Ganguli" and then to the higher right hand corners of the page "The man who provided you his name, from the man who provided you your name".

The crowning point of his inert relationship is his second love Maxine in New york: a collocation of two very different individualities - Gogol with his complex background, a first cohort American with parents who are Indian - Americans and his uneasiness with his own intelligence of the self and missing identity which delivers him with a odd individuality in consuming no identity; and Maxine, an American girl with American parentages from peers of Americans who is unconditionally comfortable with her own intelligence of the self, its steadiness and her simply - clear identity as an American. Despite Maxine's initial effort to engross him, Gogol's comatose thirst for accepting an identity and his inactiveness regarding his relationships let him yields to Maxine and Maxine's family's method of life very rapidly in their association. He leaves his own apartment and originates to live with Maxine in her parent home which is symbols of the materialistic life of the family concept Gogol's new identity.

Gogol's father expires from a heart attack in Ohio when Gogol is unmoving with Maxine. He energies there to collect his father's body and then makes for the funeral in Massachusetts. His father is deceased but what is lift of him, in his properties, his house, his wife and offspring, his friends and the memory of him are his material and social leftovers. Gogol disruptions up with Maxine because he understands that he are implicitly out of her world. He thinks that it is unbearable for her to understand and empathize with the problems of his life and his past. "He recalls Maxine's reaction to his effective her about his other name, as they'd ambitious up from his father's house.

The arrival of his association with Moushumi is also a inactive reply to his mother's will which is encouraged by his own feeling to his past and family origins particularly after his father's death. Commencement his relationship with Moushumi, Gogol is a viewer again. He arrives Moushumi's life when he is prepared to accept additional identity and self for himself finished a constructed character that 
Towards Excellence: An Indexed, Refereed \& Peer Reviewed Journal of Higher Education/Mr. Jatin Kapadiya/ Page 1-9

he sees in Moushumi particularly her experience of alive in France: "Here Moushumi had reinvented herself deprived of reservations, without guilt. He esteems her... He understands that this is what their parentages had done in America what he, in all probability, will never do". Moushumi, Gogol's wife, is the most complex character in the novel concerning the concept of individuality. Having Indian parents, being born in England, consuming lived in England, America and France composed with having numerous relations with people from varied backgrounds and nationalities, brands her an complicated character who is also in search of a secure identity without seeing it. She appears to be unwilling in tolerant a fixed and clear identity due to her way of alive.

Dishonest with the small, balding, jobless middle aged Dimitri, "She miracles if she is the solitary woman in her family ever to have deceived her husband, to have been disloyal. This is what one of her disappointments to confess: that the affair reasons her to feel oddly at peace, the difficulty of it soothing her, structuring her day". When Gogol emanates to know of it, he sensations the chill of her clandestineness numbing him, "like a poison dispersal quickly through his strains. He cannot blame her much, for they had both acted on the same impulse". Without much quarrel they both agree to separation. After the official divorce, she moves to Paris.

In the direction of the end of the novel, thoughtful upon his life and relations, Gogol is different. He feels guilty approximately his own ways of life finished the years. Family has been energetic for him now. And observing into the past he is scared to see that not lone it has remained his own routine to recklessness the family but also it is a family custom done by his parentages as well: "He miracles how his parents had complete it, leaving their individual families behindhand, seeing them to seldom, house unconnected, in a continuous state of anticipation, of longing". Anticipating "with stamina he doubts he does not own himself he had consumed years maintaining coldness from his origins a coldness that had not anxious him in the least, pending it was too late". He does not hate his name some more, in its place now that he is behind the expressive network of domestic one by one he failures the name: "deprived of people in the world to call him Gogol, no substance how long he himself lives, Gogol Ganguli will, when and for all, disappear from the lips of loved ones, and so, finish to exist.

In relating more than three periods in the Ganguli's lives, Jhumpa Lahiri has not only expected us a delightfully intimate and meaningful family representation, she has also taken the lingering chamber of music of her first group of stories and scored its themes of exile, identity equilibrium between two worlds to make a musical work, a entrance novel, 'The Namesake', that is as certain and eloquent as the effort of a long time master of the skill. The language fence that is to be the foundation of much fight for Ashima and Ashok is obvious when they reach at the hospital for Gogoi's natal after she has been assumed a bed. Ashima appearances aimed at her husband, but his recurrence after a few minutes in Bengali, a language neither the nurses nor the doctor says. The curtain is a corporal barrier, but it signifies the symbolic barrier shaped by speaking Bengali in the United States. Everything the American husbands at the hospital speak to their wives demonstrates the culture fence between India and the United states. The language fence arises as a delivered as Gogai and Sonia produce elder. Ashima and Ashoke send them to Bengali language and a culture courses every other Saturday, but it never fails to worry them, that their children complete fair like Americans. 
Towards Excellence: An Indexed, Refereed \& Peer Reviewed Journal of Higher Education/Mr. Jatin Kapadiya/ Page 1-9

\section{Conclusion}

In short, Indian Diaspora can be understood as a constituent in any one of the above kinds of contemporary societies. However, a multicultural society should find "ways of developing a strong sense of mutual commitment and common belonging without insisting upon a shared comprehensive national culture and the concomitant uniformity of values, ideals and ways of organizing significant social relations". Indian Diaspora, as a large and distinctive group which has its origin in the British colonial subjugation of the rural Indian population. It not only disturbed the traditional social structure but also created the indenture and Kangani forms of labour that led to large-scale migration of the Indian labourers to the plantations in the British colonies, starting from early eighteenth to the early twentieth century. The phenomenon of the migration took a new turn with the migration of the professionals to the developed nations; one such is the migration to the United States in the post 1960s period. 'The Namesake' is a novel that celebrates the cultural hybridity resulting from globalization and the interconnectedness of the modern world and rethinks conventional immigrant's experience. Lahiri is aware of the existing problem of cultural diversity in the multicultural United States, and she argues that the struggle to grasp a transnational identity becomes an urgent issue for immigrants in this environment. While she represents Gogol as someone who is confused about his identity, she also presents Gogol as a prototypical transnational agent who lives between two different worlds with the possibility of creating multiplicity of identities. In fact Lahiri offers a revision of the contemporary United States not as a static and insular territory but a participant in transnational relations. Given the nature of mobility of people and their culture across nations, Lahiri territorializes the definite national and cultural identities of India suggesting that individuals cannot confine themselves within the narrow concept of national and cultural boundaries in this globalized world characterized by hybridity, Transculturalism and immigration.

\section{Bibliography}

Alfonso- Forero, Ann Marie. Immigrant Motherhood and Transnationality in Jhumpa Lahiri's fiction. Literature Compass, 2007.

Caesar, Judith. Gogol's Namesake: Identity and Relationships in JhumpaLahiri's The

Namesake. Atenea 27.1, 2007.103-119.

Cohen, Robert. Global Diaspora: An Introduction. UCL Press, 1997.

Emmanuel S. Nelson:"Writers of the Indian Diaspora: A Bio-Bibliographical Critical $\quad$ Sourcebook." Print.

Ghosh, A. (n.d.): The Diaspora in Indian Culture. In The Imam and The Indian (p. 98). Delhi, India:

Ravi Dayal and Permanent Books. Print.

Huddart, David. Homi K Bhabha, London. Routledge, 2006.Print.

Lahiri, Jhumpa. The Namesake. Critique 50.1, 2008.111-125.

Lahiri, Jhumpa. The Namesake. London: Harper Collins, 2003.

Mr. Jatin Kapadiya

Assistant Professor 